\title{
Construction of the Head Finite Element Model and Craniocerebral Injury in Facial Collision Accident
}

\author{
Jie TIAN*, Qun WANG**, Bin YANG*** \\ *Nanjing Forestry University, Nanjing 210037, China, E-mail: m18362981792@163.com \\ **Nanjing Forestry University, Nanjing 210037, China, E-mail: 1328817536 @qq.com \\ ***Nanjing Institute of Technology, Nanjing 21116, China, E-mail: yangb123@126.com \\ crossref http://dx.doi.org/10.5755/j01.mech.25.3.22371
}

\section{Introduction}

In traffic accidents, head injury has become the main cause of serious injury or death. According to the WHO statistics, in road traffic accidents, the disadvantaged road users accounted for $50 \%$ of the sum number of the dead, of which pedestrians accounted for $22 \%$ of the sum number of the dead [1]. In China, the incidence of craniocerebral injury along with the number of disabled and death are all increasing annually. Therefore, it is of great practical significance to study the head injury of pedestrians.

In recent years, facial and craniocerebral injury have become a hot spot for research. In anatomy, the facial skeleton is very close to the skull. This leads to a high risk of brain injury in patients with facial injury [2], there is a certain correlation between different facial impact injuries and the severity of craniocerebral injury. With the fleeting progress of computer technology, the finite element model has become an important tool to learn about the biomechanics of human injury [3, 4]. Tuchtan et al. [5] carried out a study on the energy level required for mandibular fracture caused by direct impact of the mandible and the energy dispersion to the skull and brain. In 2015, Huempfner-Hierl [6] established a finite element model of human head without mandible, then applied this model to simulate three collision tests of the orbital margin, the thyroid gland of the nose and the upper rim of the orbit. The propagation path of the stress wave in the skull under the three collision scenarios was analysed, and the stress distribution of von Mises was obtained.

In a word, these previous studies provide effective information about the propagation of stress waves in the skull, but many of these finite element head models are too simplified, or ignore the mandible and intracranial tissue, and only aim at a small number of collisions locations, which have certain limitations for the correlation study between facial impact and traumatic brain injury.

In this research, a 50th percentile finite element model of head with detailed craniofacial structure is established. The biofidelity of the model is validated by the corpse experimental data of Nahum et al. [7] and Trosseille et al. [8]. Then this study simulates nine common face collision scenarios, clears the influence of facial impact on craniocerebral injury, provides a basis for the study of human brain injury mechanism and evaluation criteria, and also provides data reference and theoretical basis for collision protection research.

\section{The establishment and verification of the head finite element model}

\subsection{Geometric model}

Through tomography and MRI scanning in line with the body features of the 50th percentile adult Chinese male head, a tomography image has been achieved. Then this study imports the image into Mimics for pre-processing, and then obtains the point cloud data and imports it into Geomagic Studio. The point cloud data are parameterized, after generating surface, three times Bessel curve is used to fit each surface to get the $3 \mathrm{D}$ geometric model. The final $3 \mathrm{D}$ solid model of the head consists of skull, facial skeleton, cartilage, teeth, brain, cerebellum, meninges, cerebrospinal fluid, etc., as shown in Fig. 1.

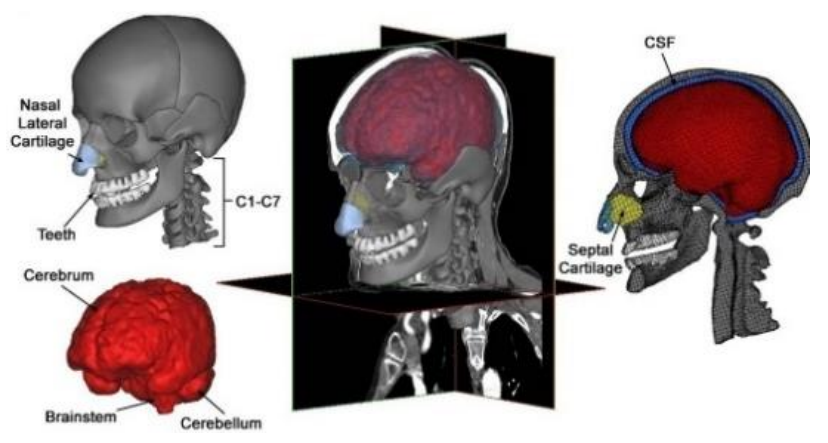

Fig. 1 Three dimensional geometric model of head

\subsection{Finite element model}

Three-dimensional geometric model is imported into HyperMesh for grid division, and then solid three-dimensional grid are generated. It's difficult to use hexahedral elements to model because of the high folds of the meninges in the model. Tetrahedron is adaptable to highly complex surface structure, so tetrahedron is more suitable for the discretization of the mesh. Thus the unit type is set as a linear tetrahedral element in this study. Finally, the three-dimensional entity model is generated and imported into Abaqus, the material properties of each tissue are shown in Table 1.

Finally, the finite element model of the head is achieved, in which the number of single element is $1,337,903$, the number of nodes are 327,536 , the average length of unit is $1.57 \mathrm{~mm}$, and a unit average aspect ratio of 1.61, as shown in Fig. 2.

\subsection{Material properties}

After meshing the model, it is necessary to assign 
material parameters corresponding to the actual situation to each part of the head finite element model. In all the latest finite element head models, skeletal tissues such as cartilage, skull and facial bone are recognized as linear elastic and isotropic materials. The linear viscoelastic material combined with large deformation theory is used to simulate the time-varying relative movement of brain tissue. The material properties used in the model are referenced in the literature [9]. The material properties are summarized in Table 1 .

Table 1

Material properties of each tissue in the model

\begin{tabular}{|c|c|c|c|c|c|c|}
\hline Components & Model Type & Density, $\mathrm{kg} / \mathrm{m}^{3}$ & $\begin{array}{c}\text { Young's modulus } \\
E, \mathrm{MPa}\end{array}$ & $\begin{array}{c}\text { Short shear } \\
\text { modulus, } \mathrm{kPa}\end{array}$ & $\begin{array}{c}\text { Long-term shear } \\
\text { modulus, } \mathrm{kPa}\end{array}$ & Poisson's ratio, $v$ \\
\hline skull & Elasticity & 2500 & 8000 & - & - & 0.22 \\
\hline facial skeleton & Elasticity & 2500 & 6000 & - & - & 0.23 \\
\hline cartilage & Elasticity & 1040 & 30 & - & - & 0.45 \\
\hline teeth & Elasticity & 2250 & 2070 & - & - & 0.3 \\
\hline meninges & Elasticity & 1140 & 11.72 & - & - & 0.23 \\
\hline brain & Linear Viscoelastic & 1140 & 2190 & 6 & 1.2 & - \\
\hline cerebellum & Linear Viscoelastic & 1140 & 2190 & 6 & 1.2 & - \\
\hline CSF & Linear viscoelastic & 1040 & 1.314 & 0.5 & 0.1 & - \\
\hline
\end{tabular}

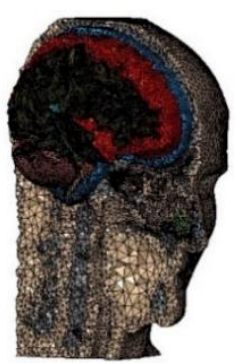

Fig. 2 Head finite element model

\subsection{Experimental verification of Nahum intracranial pres- sure}

In 1976, Nahum et al. [7] used a human cadaver without antiseptic treatment as samples. Nahum used special experimental tools to clamp the head of the cadaver to avoid the rotation acceleration of the head after impact. Then Nahum did the collision experiment of forehead. In this study, a cylindrical rigid body is used to hit the frontal bone of human head finite element model at the speed of $9.94 \mathrm{~m} / \mathrm{s}$, the horizontal plane is 45 degrees to the Frankfurt plane, as shown in Fig. 3.

In the article, Nahum only gave the various curves

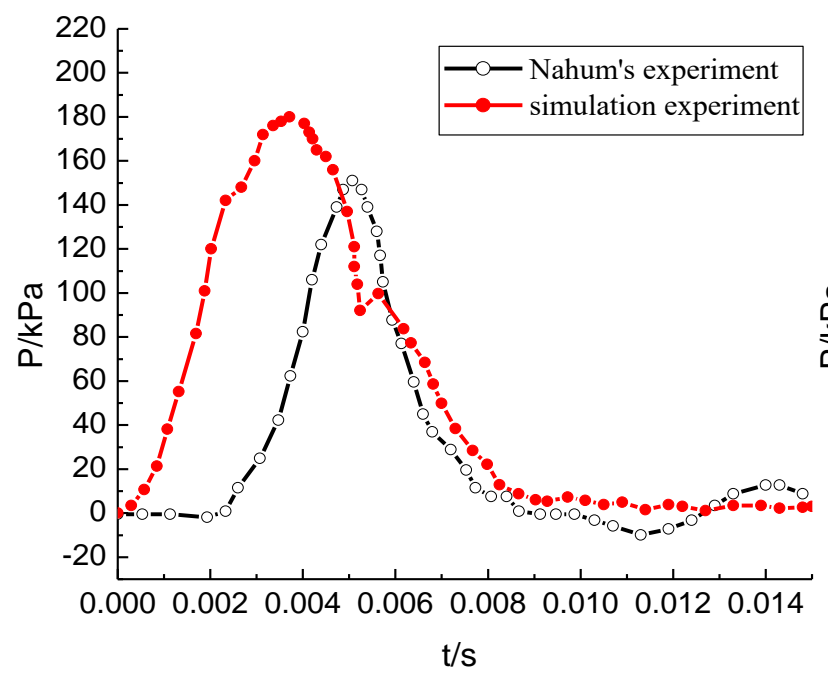

a of experimental samples numbered thirty-seventh groups. In the next 30 years, the experimental data was verified by most of the major human head finite element models. Therefore, this research compares the simulation results with the experimental curves of the thirty-seventh groups of Nahum.

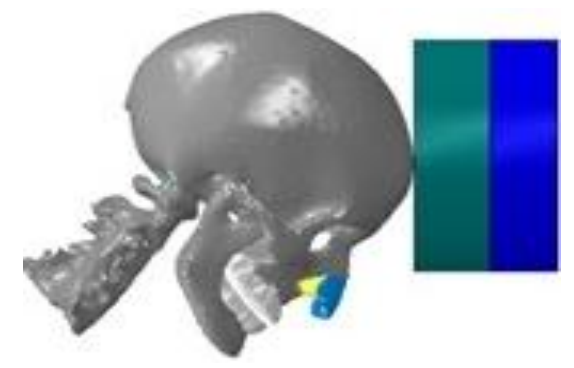

Fig. 3 Nahum et al.'s cadaver model crash experiment

Extracts pressure curve from the impact side, impact opposite side, parietal and occipital, as shown in Fig. 4. It can be seen in the four parts (a-d) of the Fig. 4 that the changing trends of the simulation curve and the experimental curve are basically the same, the curve anastomosis is good on the whole. The peak pressure in four collision regions is about $1 \mathrm{~ms}$ ahead of the experimental results of

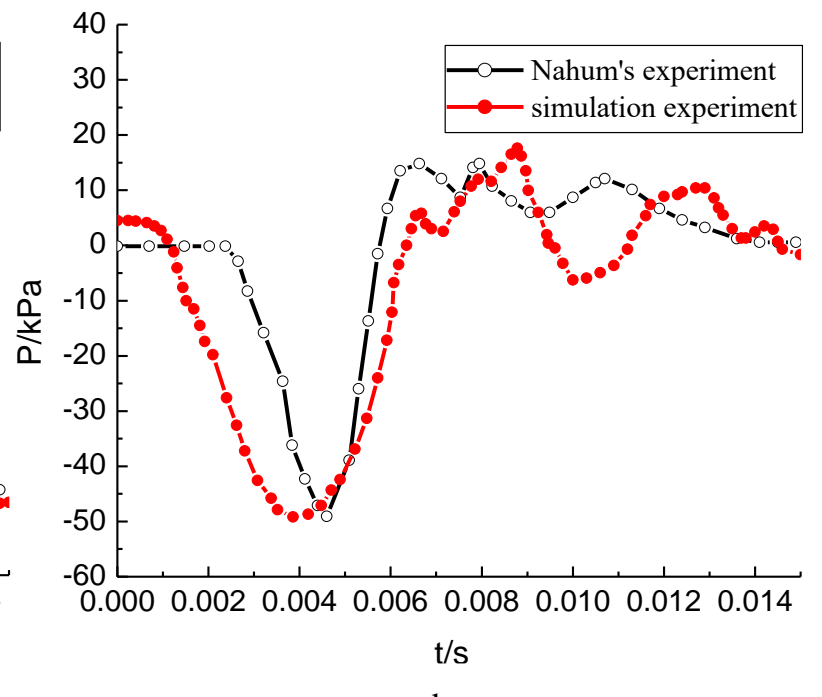

b

Fig. 4 Intracranial pressure-time curve of simulation and experiment: $\mathrm{a}$ - impact side, $\mathrm{b}$ - impact opposite side, $\mathrm{c}-$ parietal bone, $\mathrm{d}$ - occipital bone 


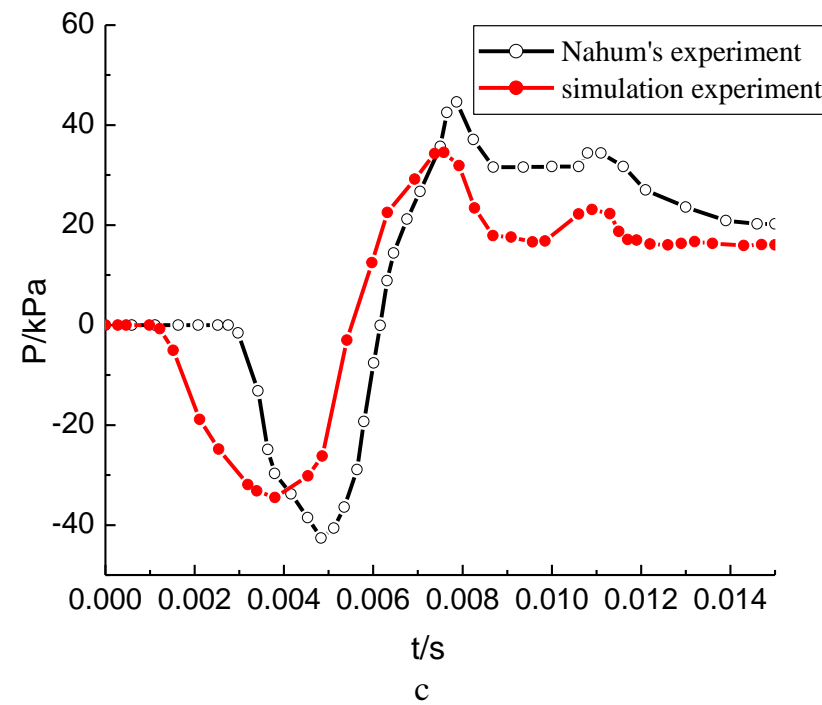

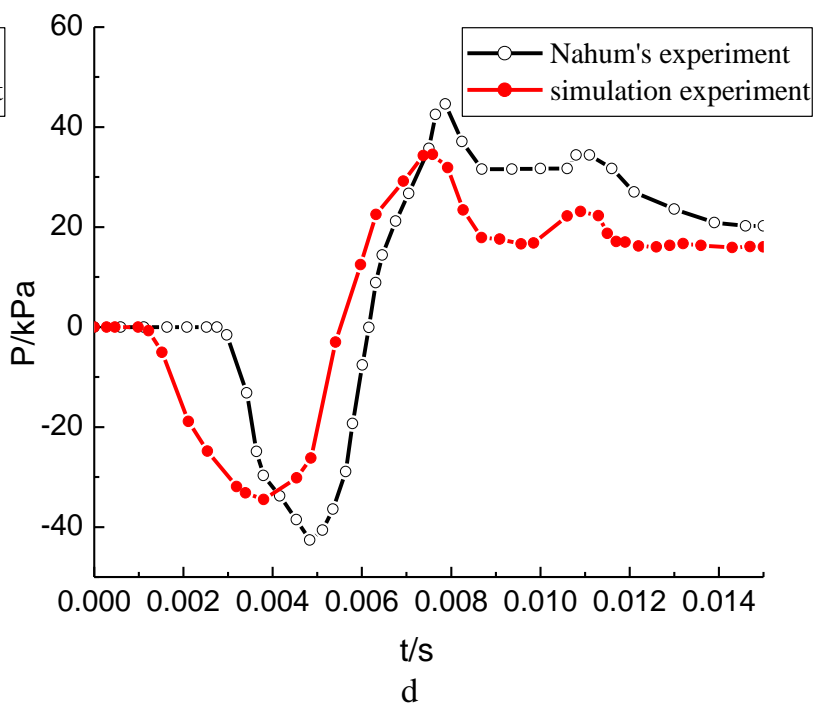

Fig. 4 Continuation

Nahum, the maximum peak is slightly different. This is mainly because there are some distinctions between the simulation model and the experimental model in the geometry size and structure, but the peak duration is roughly equal to the experimental results.

\subsection{Experimental verification of Trosseille intracranial dy- namic response}

In 1992, Trosseille et al. [8] reappeared the impact process between the human head and the car parts in a vehicle accident. This research uses steering wheel, which is modelled as a rigid cylinder with an inertial mass of $23.4 \mathrm{~kg}$, to impact at the nasal of the head finite element model. The pressure of frontal lobe, temporal lobe and occipital lobe are compared with experiment values, as shown in Fig. 5.

As can be seen from Fig. 6, the simulation curve is anastomotic well to the experimental curve, and the pressure distribution trend in three positions is similar to the experimental results. For the peak pressure, temporal and occipital peak values are more close to the experimental results, the

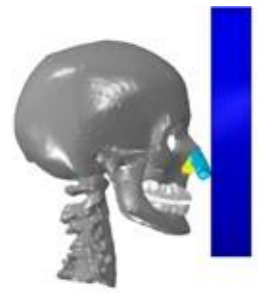

Fig. 5 Trosseille et al.'s cadaver model crash experiment

difference is less than $10 \%$, and the frontal pressure value is high. For the curve trend, frontal and occipital are consistent with experimental results and the simulation results of the temporal pressure is negative firstly, and the experimental result is almost 0 . For the peak time, the three positions are different, the duration of peak pressure is also slightly different from the experimental results. Similar deviations have also been observed in literature [10]. It may be because there are great differences between model and experimental samples. In experiment, impactor is used to impact the head, and acceleration is used to load directly in simulation, so as to avoid the influence of neck.

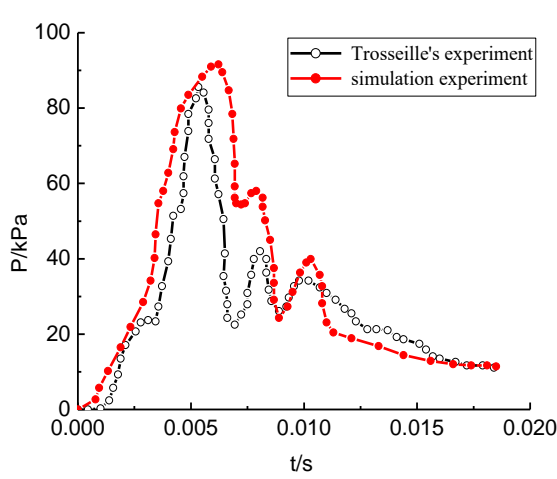

a

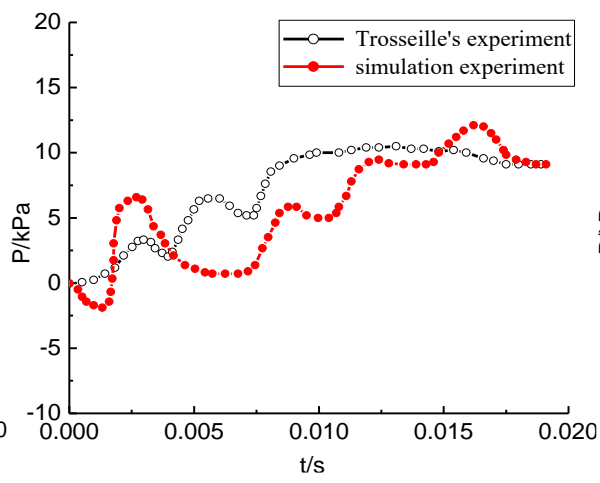

b

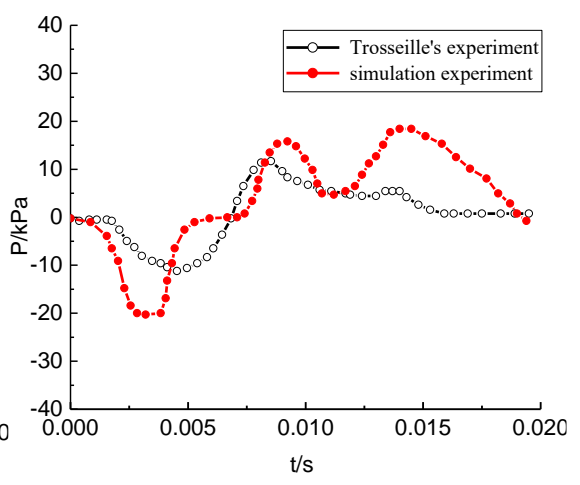

c

Fig. 6 Comparison curve between simulated pressure and experimental pressure: $\mathrm{a}$ - frontal part, $\mathrm{b}-$ partes temporalis, $\mathrm{c}-$ occiput

\section{Simulation experiment of face collision}

As shown in Fig. 7, the nine impact directions in this study are several kinds of collisions that are often encountered in real life, it contributes to a deeper understanding of the mechanism of maxillofacial and craniocerebral 
injury. Similar to the impactor used by Cormier et al. [11] in the cadaver experiment, a cylindrical rigid body is used to impact the human head finite element model at the speed of $2.5 \mathrm{~m} / \mathrm{s}$. A fixed boundary condition is imposed on the nodes of the subvertebral surface of $\mathrm{C} 7$ in the experiment, the base surface nodes of the model are constrained in all the six degrees of freedom, as shown in Fig. 8.
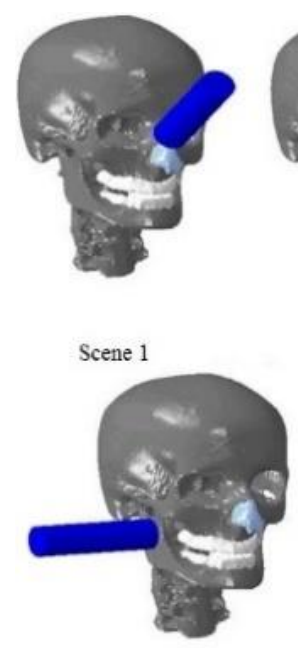

Scene 6

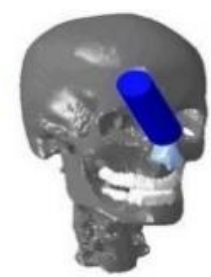

Scene 2

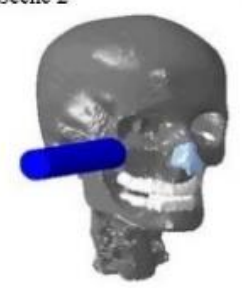

Scene 7

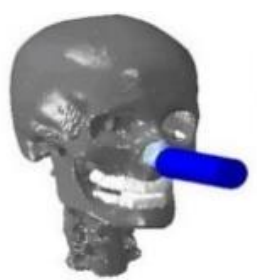

Scene 3

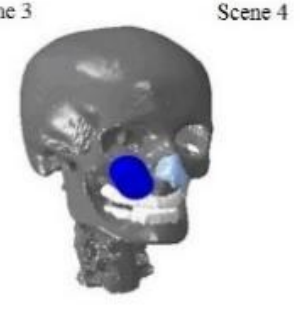

Scene 8

cene 4
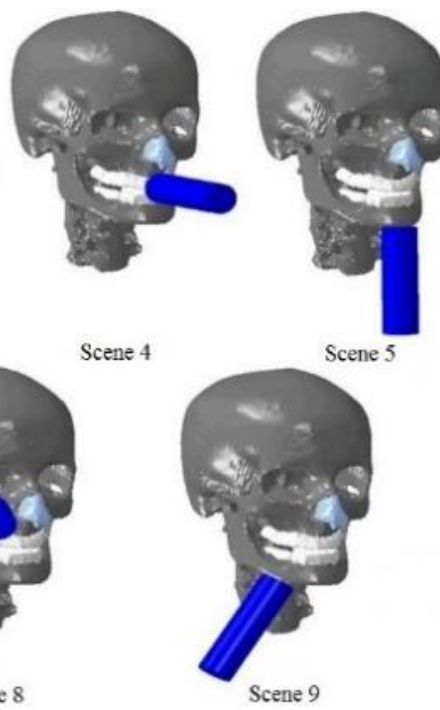

Fig. 7 Nine types of collision scenario

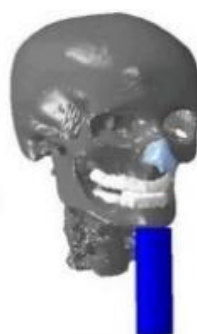

Fixed Boundary Conditions

Fig. 8 Fixed boundary conditions for surface nodes on neck

\subsection{Tolerance limit of craniocerebral injury}

To distinguish different fracture types and fracture regions, according to the previous research, von Mises stress, whose mean value is $75 \mathrm{MPa}$, is used as the yield criterion of skull. We compare the biomechanical parameters after trauma with the brain tissue tolerance limit in the literature, it can be used to evaluate traumatic brain injury.

\subsection{Simulation results discussion}

Through simulation, the propagation process of stress wave in the head of nine cases is obtained. In Scene 1 , the stress concentrates at the impact position firstly, then spreads to the bilateral frontal lobes of the maxilla and the posterior end of the nasal bone. As the base of the model is fixed, the bending of the head and neck contributes to local stress at the lower neck, it also causes the relative movement of the skull and brain, which results in stress concentration in frontal lobe and temporal lobe. At $t=2.0 \mathrm{~ms}$, there is a stress of $65 \mathrm{MPa}$ at the anterior nasal spines, nasal septum cartilage and lateral cartilage junction. According to the von Mises yield criterion, fractures occur easily around the nasal bone.

In Scene 2, starting from the impact position, stress waves propagate in two ways: one is backwards through the frontal and ethmoid plate, and then reaches the inferior frontal lobe of the brain. The other one propagates inferiorly via the perpendicular plate and nasal septum. Afterwards, the stress wave reaches the palatal floor of maxilla. On the basis of von Mises yield criterion, there is a risk of fractures at the nasal bone and bilateral maxilla frontal processes. In addition, the fracture regions also include orbital floor of maxilla, bilateral facies nasalis maxillae, cribriform plate of ethmoid bone and inferior nasal septum. In addition, mild TBI (traumatic brain injury) will appear at the temporal pole and inferior frontal lobe, and severe injury or mild DAI (diffuse axonal injury) will occur at the lateral occipito-temporal lobe and cerebellum.

In Scene 3, the stress wave passes through the upper lateral nasal cartilage and the posterior nasal bone firstly, and then spread to inferior frontal lobe from the lower lateral cartilage, then through the nasal septal cartilage and the sieve disk of plow bone, and then spread to the sphenoid from the frontal bone and ethmoidal cribriform plate. During the impact, the nasal septum cartilage and the lateral nasal cartilage are collapsed by the impactor, which leads that stress is raised and concentrated around the tip of nose and the nasal septal cartilage. According to the von Mises yield criterion, there is a risk of fracture at the anterior nasal bone and lateral nasal cartilage. Similar to Scene 1, the stress is concentrated in the frontal lobe and temporal lobe.

In Scene 4, starting from the dense incisors, a part of the stress wave passes via the alveolar processes of mandible, vomer and maxillary palatal process before reaching the sphenoid region. Another part of the stress wave reaches the bilateral maxilla frontal process through the alveolar process of mandible along the pyriform aperture, it results in local stress concentration in the temporal lobe, foramen magnum and the occipital lobe. After about $4.4 \mathrm{~ms}$, a part of the stress spreads to the exterior upper and bilateral zygomatic bone, this leads to the peak von Mises stress at the maxilla, the value of which is $203.66 \mathrm{MPa}$. Therefore, Le Fort I fracture is easy to occur at the alveolar process of mandible, at the same time, high stress is easily produced at the foramen magnum and bent lower neck.

Scene 5 is a vertical impact on the base of mandible, and Scene 9 is an oblique impact on the base of the mandible. In the process of impact, the stress wave passes through the bilateral mandibular ramus, mandibular arch and condyles, and then spreads to the zygoma along the zygomatic arch. The head is elastic during the impact, which leads to the relative rotation of the skull and brain, it makes 
the stress concentrate at the frontal lobe. In Scene 5, at $t=3.0 \mathrm{~ms}$, peak stress concentrations of $209.55 \mathrm{MPa}$ appear at the mandibular ramus and mandibular body, which is likely to lead to Le Fort III fractures in the ethmoidal cribriform plate. Moreover, Mild injury will appear at the frontal lobe, local contusion may appear at the anterior upper brainstem. At the anterior-inferior frontal lobe, it may produce mild DAI. In Scene 9, peak stress concentrations of 267.52 $\mathrm{MPa}$ appears at $\mathrm{t}=3.6 \mathrm{~ms}$, mild brain damage is likely to occur at the anterior inferior frontal lobe and temporal lobe, and concussion may produce at the frontal-temporal lobe.

In Scene 6, the stress propagates speedily to the condyle of mandible and mandible body. Then, from the right condyle of mandible, it began to propagate to the temporal bone and zygomatic bone, then to the maxilla nasal surface. The stress wave from the mandibular body propagates to the contralateral ramus of mandible. The peak stress appears at the mandibular condyle and mandibular incisor, the value of which is $328.89 \mathrm{MPa}$. Then the stress spreads dispersedly to the sphenoid bone, foramen magnum and vertebrae. After about $1.8 \mathrm{~ms}$, the lateral bending of the head causes the stress concentrate at the right frontal lobe, right parietal lobe and right temporal lobe.

In Scene 7 and Scene 8, the stress wave propagates mainly through the maxillary palatine process, the maxilla and the sphenoidal orbit surfaces to the sphenoid and middle surface structures. In Scene 7, peak stress of 244.69 MPa appears at the zygomatic region after about $1 \mathrm{~ms}$, and there is local stress concentration on the maxilla, zygomatic orbit surfaces and frontal process of the zygoma. In Scene 8, peak stress of $537.94 \mathrm{MPa}$ appears at the zygoma after about 1.2 $\mathrm{ms}$. In the two cases, there are a large number of stress concentration at the zygomatic and maxillary orbit surfaces, particularly in Scene 8, because the collision position is proximal to the orbital area. Although the stress concentrations in Scene 7 and Scene 8 are lower than that in Scene 6, there is still a higher stress concentration at the anterior-inferior frontal lobe and right temporal lobe, which is due to the large relative displacement between the frontal lobe and frontal area of skull.

Maximum of intracranial biomechanical parameters

Table 2

\begin{tabular}{|c|c|c|c|c|c|c|c|c|c|c|c|c|}
\hline \multirow{2}{*}{ Scene } & \multicolumn{2}{|c|}{$\mathrm{ICP}(\mathrm{MPa})$} & \multicolumn{2}{|c|}{ von Mises(MPa) } & \multicolumn{6}{|c|}{ Shear stress $(\mathrm{MPa})$} & \multicolumn{2}{|c|}{ Strain } \\
\hline & $P_{\max }$ & Position & $\sigma_{\max }$ & Position & $\tau_{12 \max }$ & Position & $\tau_{13 \max }$ & Position & $\tau_{23 \max }$ & Position & $\varepsilon$ & Position \\
\hline \multirow{2}{*}{1} & $\begin{array}{c}2.36 \\
7 \mathrm{E}- \\
01 \\
\end{array}$ & $\begin{array}{c}\text { Inferior } \\
\text { frontal } \\
\text { lobe }\end{array}$ & $\begin{array}{c}2.59 \\
7 \mathrm{E}- \\
02 \\
\end{array}$ & $\begin{array}{c}\text { Inferior } \\
\text { frontal } \\
\text { lobe } \\
\end{array}$ & $\begin{array}{l}1.143 \\
\text { E-02 }\end{array}$ & $\begin{array}{c}\text { Upper } \\
\text { brainstem }\end{array}$ & $\begin{array}{c}-1.635 \\
\text { E-02 }\end{array}$ & $\begin{array}{l}\text { Frontal } \\
\text { lobe }\end{array}$ & $\begin{array}{l}1.578 \\
\text { E-02 }\end{array}$ & $\begin{array}{c}\text { Inferior } \\
\text { frontal } \\
\text { lobe } \\
\end{array}$ & $\begin{array}{l}8.858 \\
\text { E-02 }\end{array}$ & $\begin{array}{c}\text { Inferior } \\
\text { frontal } \\
\text { lobe } \\
\end{array}$ \\
\hline & & & $\begin{array}{c}1.80 \\
7 \mathrm{E}- \\
02 \\
\end{array}$ & $\begin{array}{l}\text { Parahip- } \\
\text { pocampal } \\
\text { gyrus } \\
\end{array}$ & $\begin{array}{l}-1.196 \\
\text { E-02 }\end{array}$ & $\begin{array}{c}\text { Inferior } \\
\text { frontal lobe }\end{array}$ & & $\begin{array}{c}\text { Posterior } \\
\text { cerebel- } \\
\text { lum } \\
\end{array}$ & $\begin{array}{c}-1.537 \\
\text { E-02 }\end{array}$ & $\begin{array}{c}\text { Anterior } \\
\text { frontal } \\
\text { lobe }\end{array}$ & $\begin{array}{l}8.082 \\
\text { E-02 }\end{array}$ & $\begin{array}{c}\text { Inferior } \\
\text { temporal } \\
\text { gyrus } \\
\end{array}$ \\
\hline \multirow{2}{*}{2} & $\begin{array}{c}2.34 \\
0 \mathrm{E}- \\
01\end{array}$ & $\begin{array}{l}\text { Anterior } \\
\text { frontal } \\
\text { lobe }\end{array}$ & $\begin{array}{c}2.27 \\
0 \mathrm{E}- \\
02\end{array}$ & $\begin{array}{l}\text { Inferior } \\
\text { frontal } \\
\text { lobe }\end{array}$ & $\begin{array}{l}1.298 \\
\text { E-02 }\end{array}$ & $\begin{array}{c}\text { Frontal } \\
\text { lobe and } \\
\text { anterior } \\
\text { callosum } \\
\end{array}$ & $\begin{array}{l}1.549 \\
\text { E-02 }\end{array}$ & $\begin{array}{l}\text { Occipi- } \\
\text { totemporal } \\
\text { gyrus }\end{array}$ & $\begin{array}{l}1.117 \\
\text { E-02 }\end{array}$ & $\begin{array}{c}\text { Medial oc- } \\
\text { cipitotem- } \\
\text { poral gy- } \\
\text { rus } \\
\end{array}$ & $\begin{array}{l}1.273 \\
\text { E-01 }\end{array}$ & $\begin{array}{c}\text { Temporal } \\
\text { pole }\end{array}$ \\
\hline & $\begin{array}{c}2.29 \\
5 \mathrm{E}- \\
01\end{array}$ & $\begin{array}{l}\text { Inferior } \\
\text { frontal } \\
\text { lobe }\end{array}$ & & & $\begin{array}{l}-1.147 \\
\text { E-02 }\end{array}$ & $\begin{array}{c}\text { Posterior } \\
\text { cerebellum }\end{array}$ & $\begin{array}{c}-1.517 \\
\text { E-02 }\end{array}$ & $\begin{array}{l}\text { Lateral oc- } \\
\text { cipitotem- } \\
\text { poral gy- } \\
\text { rus } \\
\end{array}$ & $\begin{array}{c}-1.165 \\
\text { E-02 }\end{array}$ & $\begin{array}{l}\text { Inferior } \\
\text { frontal } \\
\text { lobe }\end{array}$ & & \\
\hline \multirow[t]{2}{*}{3} & $\begin{array}{c}1.01 \\
4 \mathrm{E}- \\
01\end{array}$ & $\begin{array}{l}\text { Anterior } \\
\text { frontal } \\
\text { lobe }\end{array}$ & $\begin{array}{c}5.72 \\
4 \mathrm{E}- \\
03\end{array}$ & $\begin{array}{l}\text { Anterior } \\
\text { frontal } \\
\text { lobe }\end{array}$ & $\begin{array}{l}3.146 \\
\text { E-03 }\end{array}$ & $\begin{array}{c}\text { Anterior } \\
\text { brainstem }\end{array}$ & $\begin{array}{l}3.621 \\
\text { E-03 }\end{array}$ & $\begin{array}{l}\text { Subcallo- } \\
\text { sal gyrus }\end{array}$ & $\begin{array}{l}6.121 \\
E-03\end{array}$ & $\begin{array}{l}\text { Anterior- } \\
\text { inferior } \\
\text { frontal } \\
\text { lobe }\end{array}$ & $\begin{array}{c}2.296 \\
\text { E-02 }\end{array}$ & $\begin{array}{c}\text { Anterior- } \\
\text { inferior } \\
\text { frontal } \\
\text { lobe }\end{array}$ \\
\hline & & & & & $\begin{array}{l}-4.574 \\
\text { E- } 03\end{array}$ & $\begin{array}{c}\text { Anterior } \\
\text { frontal lobe }\end{array}$ & $\begin{array}{c}-3.435 \\
\mathrm{E}-03\end{array}$ & $\begin{array}{l}\text { Paracen- } \\
\text { tral gyrus }\end{array}$ & $\begin{array}{c}-4.823 \\
\text { E-03 }\end{array}$ & $\begin{array}{c}\text { Anterior } \\
\text { frontal } \\
\text { lobe } \\
\end{array}$ & & \\
\hline \multirow[t]{2}{*}{4} & $\begin{array}{c}1.61 \\
8 \mathrm{E}- \\
01\end{array}$ & $\begin{array}{l}\text { Inferior } \\
\text { frontal } \\
\text { lobe }\end{array}$ & $\begin{array}{c}1.72 \\
7 \mathrm{E}- \\
02\end{array}$ & $\begin{array}{l}\text { Inferior } \\
\text { frontal } \\
\text { lobe }\end{array}$ & $\begin{array}{l}1.205 \\
E-02\end{array}$ & $\begin{array}{c}\text { Posterior } \\
\text { medulla ob- } \\
\text { longata }\end{array}$ & $\begin{array}{l}9.950 \\
\text { E-03 }\end{array}$ & $\begin{array}{l}\text { Parieto- } \\
\text { occipital } \\
\text { lobe }\end{array}$ & $\begin{array}{c}-1.020 \\
\text { E-02 }\end{array}$ & $\begin{array}{c}\text { Medulla } \\
\text { oblongata }\end{array}$ & $\begin{array}{l}8.072 \\
\text { E-02 }\end{array}$ & $\begin{array}{l}\text { Occipi- } \\
\text { totem- } \\
\text { poral gy- } \\
\text { rus }\end{array}$ \\
\hline & $\begin{array}{c}1.16 \\
6 \mathrm{E}- \\
01\end{array}$ & $\begin{array}{l}\text { Anterior } \\
\text { frontal } \\
\text { lobe }\end{array}$ & $\begin{array}{c}1.81 \\
6 \mathrm{E}- \\
02\end{array}$ & $\begin{array}{l}\text { Parahip- } \\
\text { pocampal } \\
\text { gyrus }\end{array}$ & $\begin{array}{l}-1.000 \\
\mathrm{E}-02\end{array}$ & $\begin{array}{c}\text { Posterior } \\
\text { medulla ob- } \\
\text { longata }\end{array}$ & $\begin{array}{c}-1.062 \\
\text { E-02 }\end{array}$ & $\begin{array}{c}\text { Posterior } \\
\text { medulla } \\
\text { oblongata }\end{array}$ & $\begin{array}{l}9.857 \\
\text { E-03 }\end{array}$ & $\begin{array}{l}\text { Medulla } \\
\text { oblongata }\end{array}$ & & \\
\hline \multirow{2}{*}{5} & $\begin{array}{c}1.83 \\
9 \\
\text { E-01 }\end{array}$ & $\begin{array}{l}\text { Anterior- } \\
\text { inferior } \\
\text { frontal } \\
\text { lobe } \\
\end{array}$ & $\begin{array}{c}1.35 \\
2 \mathrm{E}- \\
02\end{array}$ & $\begin{array}{c}\text { Inferior } \\
\text { frontal } \\
\text { lobe }\end{array}$ & $\begin{array}{l}9.477 \\
\mathrm{E}-03\end{array}$ & $\begin{array}{c}\text { Anterior } \\
\text { brainstem }\end{array}$ & $\begin{array}{c}2.012 \\
\text { E-02 }\end{array}$ & $\begin{array}{l}\text { Inferior } \\
\text { frontal } \\
\text { lobe }\end{array}$ & $\begin{array}{l}1.365 \\
\text { E-02 }\end{array}$ & $\begin{array}{l}\text { Frontal pa- } \\
\text { rietal lobe }\end{array}$ & $\begin{array}{l}7.753 \\
\text { E-02 }\end{array}$ & $\begin{array}{c}\text { Temporal } \\
\text { lobe }\end{array}$ \\
\hline & & & & & $\begin{array}{l}-1.002 \\
\mathrm{E}-02\end{array}$ & $\begin{array}{l}\text { Occipital } \\
\text { lobe and } \\
\text { superior } \\
\text { cerebellum }\end{array}$ & $\begin{array}{c}-1.448 \\
\text { E-02 }\end{array}$ & $\begin{array}{l}\text { Posterior } \\
\text { callosum }\end{array}$ & $\begin{array}{c}-1.679 \\
\text { E-02 }\end{array}$ & $\begin{array}{l}\text { Anterior- } \\
\text { inferior } \\
\text { frontal } \\
\text { lobe }\end{array}$ & & \\
\hline \multirow[t]{2}{*}{6} & $\begin{array}{c}1.40 \\
1 \\
\text { E-01 }\end{array}$ & $\begin{array}{l}\text { Orbital } \\
\text { gyrus and } \\
\text { frontal- } \\
\text { temporal } \\
\text { lobe }\end{array}$ & $\begin{array}{c}1.76 \\
9 \mathrm{E}- \\
02\end{array}$ & $\begin{array}{l}\text { Posterior } \\
\text { cerebel- } \\
\text { lum }\end{array}$ & $\begin{array}{l}1.004 \\
\text { E-02 }\end{array}$ & $\begin{array}{c}\text { Posterior } \\
\text { cerebellum }\end{array}$ & $\begin{array}{l}8.885 \\
\text { E-03 }\end{array}$ & $\begin{array}{c}\text { Anterior } \\
\text { brainstem }\end{array}$ & $\begin{array}{l}1.230 \\
\text { E-02 }\end{array}$ & $\begin{array}{l}\text { Anterior- } \\
\text { inferior } \\
\text { cerebellum }\end{array}$ & $\begin{array}{l}4.118 \\
\text { E-02 }\end{array}$ & $\begin{array}{l}\text { Posterior- } \\
\text { inferior } \\
\text { brainstem }\end{array}$ \\
\hline & & & & & $\begin{array}{l}-1.078 \\
\text { E-02 }\end{array}$ & $\begin{array}{c}\text { Anterior } \\
\text { cerebellum }\end{array}$ & $\begin{array}{l}-1.116 \\
\text { E-02 }\end{array}$ & $\begin{array}{l}\text { Posterior } \\
\text { cerebel- } \\
\text { lum }\end{array}$ & $\begin{array}{c}-1.048 \\
\text { E-02 }\end{array}$ & $\begin{array}{l}\text { Posterior- } \\
\text { superior } \\
\text { cerebellum }\end{array}$ & & \\
\hline
\end{tabular}


Table 2 continuation

\begin{tabular}{|c|c|c|c|c|c|c|c|c|c|c|c|c|}
\hline \multirow{2}{*}{ Scene } & \multicolumn{2}{|c|}{$\mathrm{ICP}(\mathrm{MPa})$} & \multicolumn{2}{|c|}{ von Mises(MPa) } & \multicolumn{6}{|c|}{ Shear stress (MPa) } & \multicolumn{2}{|c|}{ Strain } \\
\hline & $P_{\max }$ & Position & $\sigma_{\max }$ & Position & $\tau_{12 \max }$ & Position & $\tau_{13 \max }$ & Position & $\tau_{23 \max }$ & Position & $\varepsilon$ & Position \\
\hline \multirow{2}{*}{7} & $\begin{array}{c}1.86 \\
6 \\
\text { E- } 01\end{array}$ & $\begin{array}{c}\text { Temporal } \\
\text { lobe }\end{array}$ & $\begin{array}{c}2.15 \\
2 \mathrm{E}- \\
02\end{array}$ & $\begin{array}{l}\text { Frontal- } \\
\text { temporal } \\
\text { lobe }\end{array}$ & $\begin{array}{l}1.456 \\
\mathrm{E}-02\end{array}$ & $\begin{array}{l}\text { Medial } \\
\text { frontal gy- } \\
\text { rus }\end{array}$ & $\begin{array}{l}1.796 \\
\mathrm{E}-02\end{array}$ & $\begin{array}{c}\text { Anterior- } \\
\text { superior } \\
\text { cerebel- } \\
\text { lum }\end{array}$ & $\begin{array}{l}1.668 \\
\mathrm{E}-02\end{array}$ & $\begin{array}{l}\text { Medial } \\
\text { frontal gy- } \\
\text { rus }\end{array}$ & $\begin{array}{l}9.452 \\
\text { E-02 }\end{array}$ & $\begin{array}{l}\text { Frontal- } \\
\text { temporal } \\
\text { lobe }\end{array}$ \\
\hline & & & & & $\begin{array}{c}-1.807 \\
\mathrm{E}-02\end{array}$ & $\begin{array}{c}\text { Temporal } \\
\text { lobe }\end{array}$ & $\begin{array}{c}-1.460 \\
\text { E-02 }\end{array}$ & $\begin{array}{l}\text { Superior } \\
\text { frontal gy- } \\
\text { rus }\end{array}$ & $\begin{array}{c}-1.755 \\
\mathrm{E}-02\end{array}$ & $\begin{array}{l}\text { Inferior } \\
\text { frontal } \\
\text { lobe }\end{array}$ & & \\
\hline \multirow[t]{2}{*}{8} & $\begin{array}{c}2.07 \\
6 \\
\text { E-01 }\end{array}$ & $\begin{array}{c}\text { Anterior- } \\
\text { inferior } \\
\text { frontal } \\
\text { lobe }\end{array}$ & $\begin{array}{c}2.00 \\
3 \mathrm{E}- \\
02\end{array}$ & $\begin{array}{l}\text { Frontal- } \\
\text { temporal } \\
\text { lobe }\end{array}$ & $\begin{array}{l}1.567 \\
\mathrm{E}-02\end{array}$ & $\begin{array}{c}\text { Anterior } \\
\text { brainstem }\end{array}$ & $\begin{array}{l}1.626 \\
\mathrm{E}-02\end{array}$ & $\begin{array}{l}\text { Ante- } \\
\text { rior brain- } \\
\text { stem }\end{array}$ & $\begin{array}{l}1.378 \\
\mathrm{E}-02\end{array}$ & $\begin{array}{c}\text { Anterior- } \\
\text { inferior } \\
\text { frontal } \\
\text { lobe }\end{array}$ & $\begin{array}{c}9.603 \\
\text { E-02 }\end{array}$ & $\begin{array}{l}\text { Frontal- } \\
\text { temporal } \\
\text { lobe }\end{array}$ \\
\hline & & & & & $\begin{array}{c}-1.184 \\
\mathrm{E}-02\end{array}$ & $\begin{array}{l}\text { Anterior } \\
\text { cerebellum }\end{array}$ & $\begin{array}{c}-1.896 \\
\mathrm{E}-02\end{array}$ & $\begin{array}{l}\text { Ante- } \\
\text { rior frontal } \\
\text { lobe }\end{array}$ & $\begin{array}{c}-1.322 \\
\mathrm{E}-02\end{array}$ & $\begin{array}{l}\text { Posterior } \\
\text { cerebellum }\end{array}$ & & \\
\hline \multirow{2}{*}{9} & $\begin{array}{c}1.63 \\
3 \\
\mathrm{E}-01\end{array}$ & $\begin{array}{c}\text { Anterior- } \\
\text { inferior } \\
\text { frontal } \\
\text { lobe }\end{array}$ & $\begin{array}{l}1.88 \\
1 \mathrm{E}- \\
02\end{array}$ & $\begin{array}{c}\text { Temporal } \\
\text { pole }\end{array}$ & $\begin{array}{l}1.341 \\
\mathrm{E}-02\end{array}$ & $\begin{array}{c}\text { Anterior } \\
\text { brainstem }\end{array}$ & $\begin{array}{l}1.937 \\
\mathrm{E}-02\end{array}$ & $\begin{array}{c}\text { Tem- } \\
\text { poral pole } \\
\text { of cere- } \\
\text { brum }\end{array}$ & $\begin{array}{l}1.026 \\
\mathrm{E}-02\end{array}$ & $\begin{array}{l}\text { Medial } \\
\text { frontal gy- } \\
\text { rus }\end{array}$ & $\begin{array}{c}4.191 \\
\mathrm{E}-02\end{array}$ & $\begin{array}{c}\text { Temporal } \\
\text { lobe }\end{array}$ \\
\hline & & & & & $\begin{array}{c}-1.020 \\
\text { E-02 }\end{array}$ & $\begin{array}{l}\text { Occipital } \\
\text { lobe }\end{array}$ & $\begin{array}{c}-9.354 \\
\text { E-03 }\end{array}$ & $\begin{array}{l}\text { Poste- } \\
\text { rior callo- } \\
\text { sum }\end{array}$ & $\begin{array}{c}-1.905 \\
\mathrm{E}-02\end{array}$ & $\begin{array}{l}\text { Anterior- } \\
\text { inferior } \\
\text { frontal } \\
\text { lobe }\end{array}$ & & \\
\hline
\end{tabular}

\subsection{Intracranial biomechanical parameters}

In the nine impact scenarios, when the impact force reaches the peak value, the maximum values of the intracranial biomechanical parameters of these positions are achieved, as shown in Table 2. Meanwhile, the contour plots of median sagittal plane as shown in Fig. 9 to Fig. 13 are obtained.

\subsubsection{Intracranial Pressure (ICP)}

Fig. 9 indicates that the maximum ICP of frontal collision and mandibular base impact appears at the inferior frontal lobe, which is close to the mid-sagittal plane, while the maximum ICP appears near the impact side in lateral impact. Among all the scenes, the frontal collisions at the nasal bone (Scene 1 and Scene 2) are the most serious, and their peak pressure are close to the brain tolerance limit of $235 \mathrm{kPa}$. The second are the oblique impacts at the zygomatic maxillary area (Scene 7 and Scene 8), the peak pressure appears at the frontal-temporal lobe. In the various impacts of the mandible (Scene 5, Scene 6 and Scene 9), the ICP value has a moderate increase. In frontal impacts (Scene 3 and Scene 4), the intracranial pressure in the lateral cartilage and teeth are relatively low.

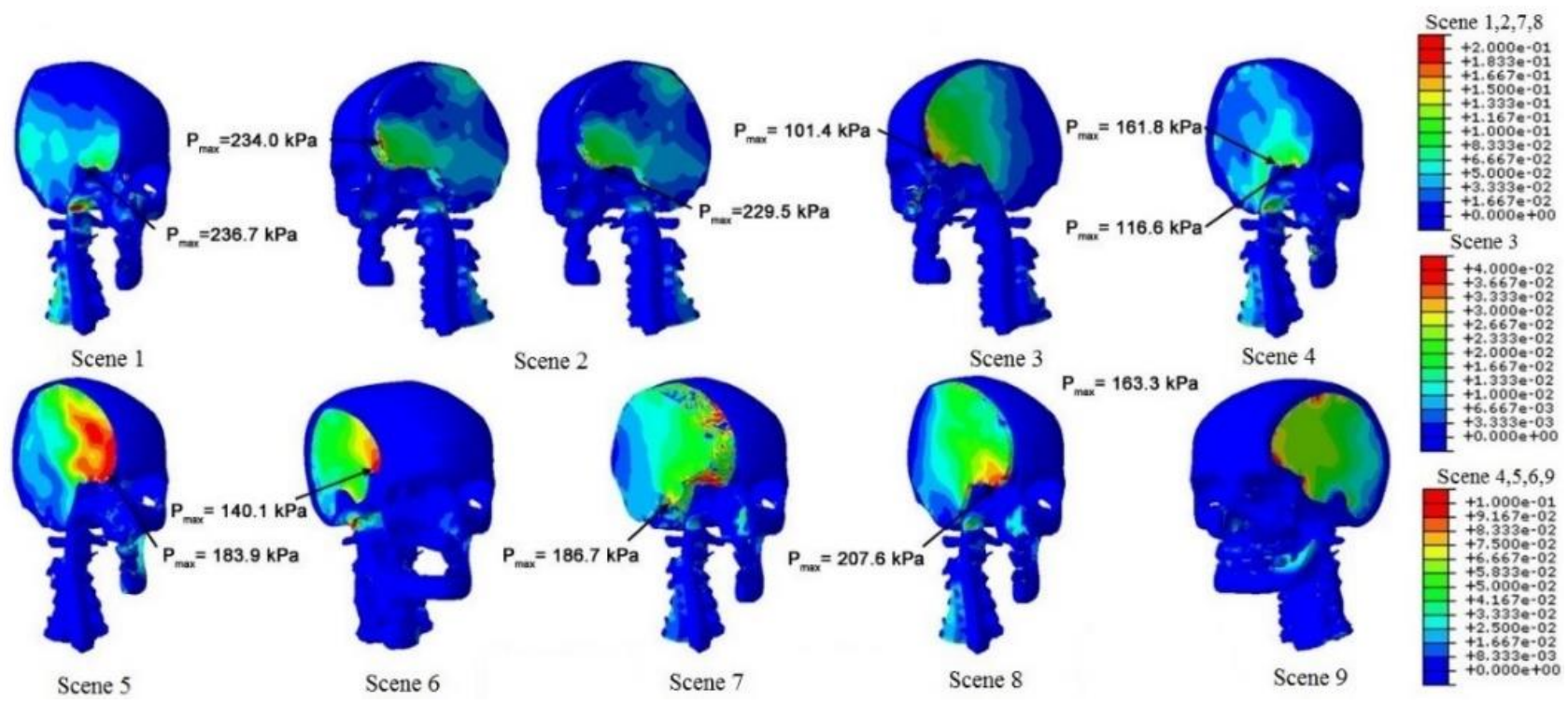

Fig. 9 ICP of the nine scenes

\subsubsection{Von Mises stress}

As shown in Fig. 10, the maximum von Mises stress appears at the frontal-temporal lobe and frontal lobe. While in Scene 6, the peak von Mises stress is situated at the posterior cerebellum. In all cases, Scene 1 and Scene 2 are the nasal bone impacts, which are the most serious, came along by lateral impacts (Scene 7 and Scene 8), which has the risk of mild TBI (traumatic brain injury). When the maximum von Mises stress is produced by the frontal collision on teeth (Scene 4) and the base impact on the mandible 
(Scene 9), it may develop into moderate neurological lesions. The injury caused by frontal collision on the lateral nasal cartilage (Scene 3) is the lowest, with the maximum stress of $5.72 \mathrm{kPa}$, there is a risk of producing local contusion [7].

\subsubsection{Shear stress}

From Fig. 11 to Fig. 13, we can see that in all cases, the critical shear stress positions are mainly in three directions (i.e., fore-and-aft, left-right, up-down). In the lateral collisions on the zygomatic maxillary bone (Scene 7 and Scene 8), the maximum shear stress is generated in the leftright direction, whereas the base collisions at the mandible lead to the maximum shear deformation of the brain tissue in the up-down direction. According to the tolerance limit of shear stress, except Scene 3, there is a possibility of mild TBI or mild DAI in most scenes.
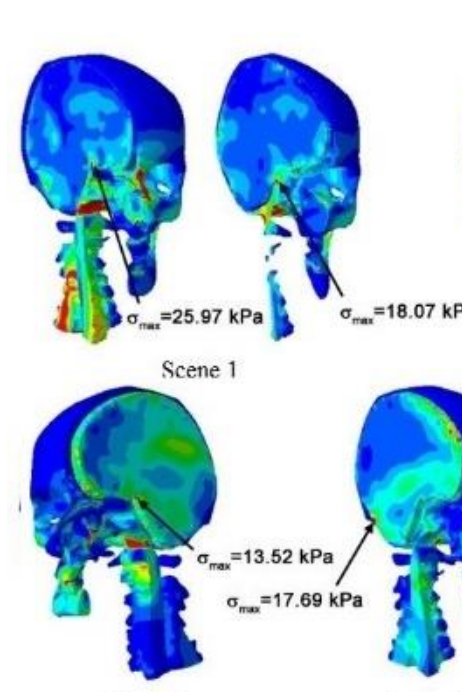

Scene 5

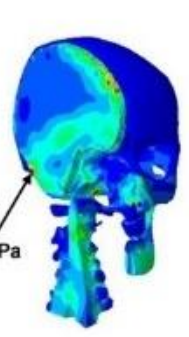

Scene 6

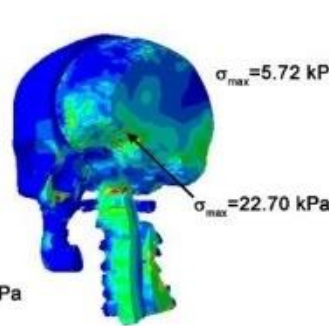

Scene 2

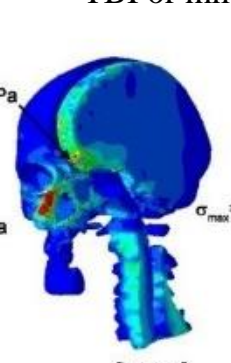

Scene 3

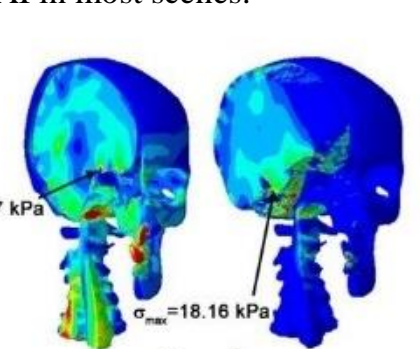

Scene 4

Fig. 10 Von Mises stress of the nine scenes

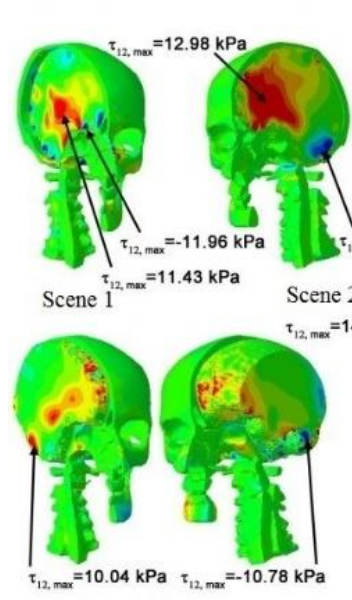

Scene 6

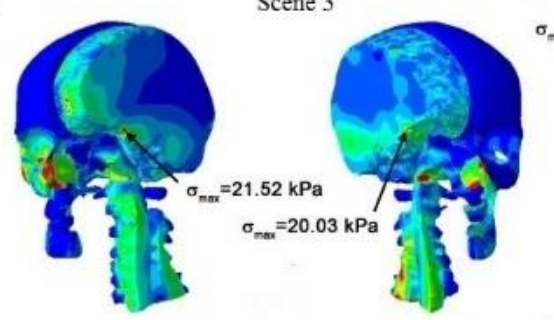

Scene 7

Scene 8

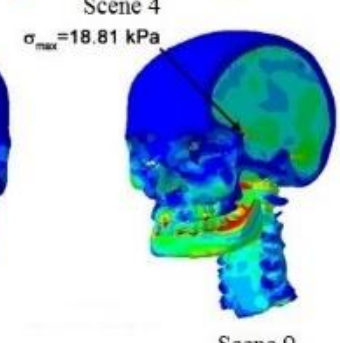

Scene 9

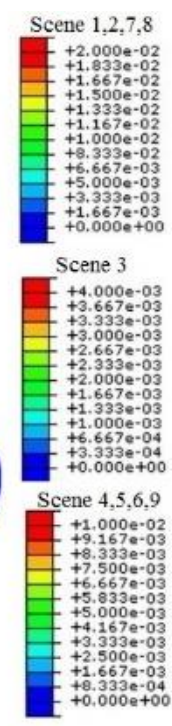

$+0.000++0$
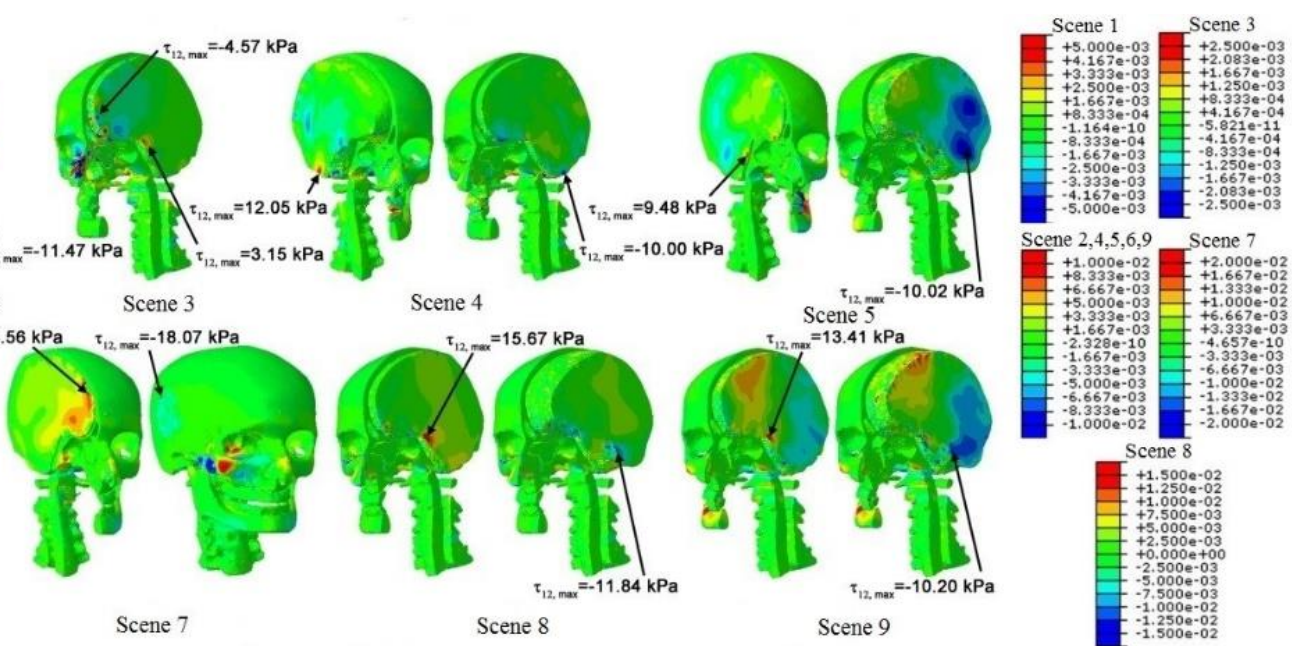

Fig. 11 Shear stress $\left(\tau_{12}\right)$ of the nine scenes

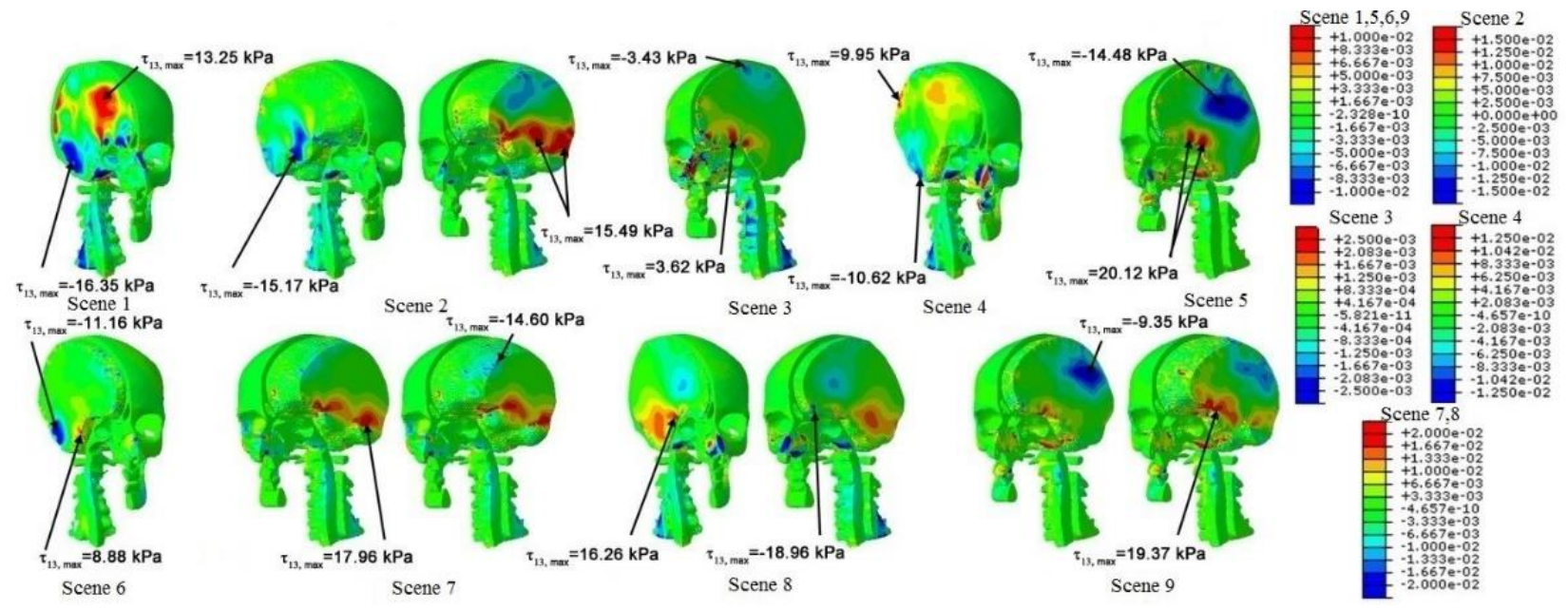

Fig. 12 Shear stress $\left(\tau_{13}\right)$ of the nine scenes 


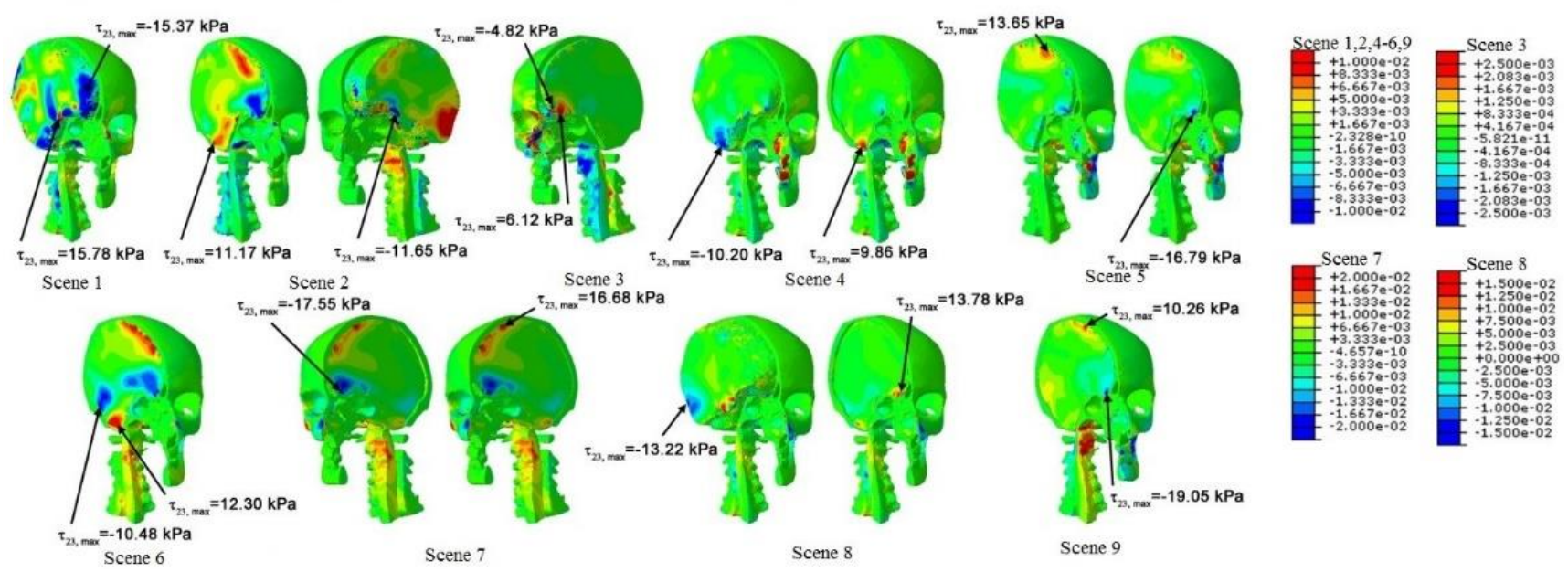

Fig. 13 Shear stress $\left(\tau_{23}\right)$ of the nine scenes

\section{Discussion}

In frontal impact on nasal bone, the general trend of maximal intracranial parameters reveals that the distance from the impact position to the brain determines the severity of brain injury, as well as in the lateral impacts at the zygomatic maxillary region. It verifies the conclusion of Lee: "The risk of TBI caused by facial fractures adjacent to the brain is very high."

In Scenes 1, 2 and 4, they are likely to result in maxillary fractures, which are normally accompanied by nasoethmoidal fractures, it will further lead to the occurrence of mild DAI at the medulla oblongata. Meanwhile, moderate neurological lesions will appear at the frontal-temporal lobe. Just like Chang's hypothesis: "a structure is formed by maxilla and other facial bones in midface, which can absorb considerable energy." When the face is impacted, a portion of collision energy is assimilated by the midfacial structure, and the other energy is transferred to the intracranium.

Nasal bone fractures are found in Scenes 1, 2 and 3 , but in Scene 3, the risk of skull fractures and craniocerebral injuries is the lowest, because nasal lateral cartilage has less rigid structure, so it can absorb impact energy by means of deformation and fractures. In accordance with the clinical review of Weller et al. [13], this research also illustrates that the nasal cartilages can behave as a buffer region to decrease the impact force that will transmit to the skull and minimize the risk of severe traumatic brain injuries.

Mandibular fractures may exist in Scenes 5, 6 and 9 , the associated facial fractures also include rami mandibulae, coronoid process of mandible and bilateral facies nasalis maxillae. Thus, the incidental brain traumas range from mild recoverable injury to mild DAI in the brainstem, cerebellum as well as inferior frontal lobe. Mandibular fracture is usually accompanied by midfacial fracture, though the mandible is not close to the brain Therefore, it still causes mild to moderate traumatic brain injury.

The propagation of stress waves in cranial bones decides the onset and progression of various facial fracture patterns. Moreover, it has important clinical significance for the mechanism research of intracranial injury. This study shows that a large number of impact energy is transmitted to the brain through the facial structure, that is, the collisions do not affect the brain directly. Nevertheless, it can be found that stress waves are mainly concentrated in the prefrontal lobe before stress wave passes through the frontal sinuses.
It indicates that the relative motion of skull and brain leads to the elevation of frontal lobe stress, in which it strikes the protuberance of the skull internal surface, rather than the stress wave propagation.

The results show that in most scenes, the von Mises stress at the VE region is higher, it is consistent with clinical diagnosis. According to the study of Aykan et al. [14], the plowbone ethmoid located at the posterior part of nasal septum cartilage is the most common fracture area. This suggests that the skeletal structure in the middle of the face may be the focus of stress transmission, where the collision energy is further dissipated to "buffer zone" of the ethmoid sinus, reducing the risk of craniocerebral injury.

\section{Conclusions}

By establishing and verifying a fifty percentile head finite element model with detailed craniofacial characteristics, and simulating nine kinds of common facial impact scenes, we get the following conclusions:

1. When the face is impacted, the facial structure can protect the brain by assimilating a lot of impact energy through deformation and fracture, thereby decreasing the risk of craniocerebral injury.

2. According to the shear stress tolerance, facial impact may lead to TBI or DAI. Even patients with minor facial injuries may lead to craniocerebral injury.

3. The propagation path and distribution rule of stress waves in the skull and brain determine the mechanism of craniocerebral impact injury, which provide a theoretical basis for the diagnosis, treatment and protection of craniocerebral injury caused by facial impact.

\section{Acknowledgment}

BY, QW and JT contributed equally to this study and share the first authorship.

\section{Funding}

This study was supported by the Natural Science Foundation of Jiangsu Province, China (Grant No. BK20161522), Six Talent Peaks Project in Jiangsu Province, China (Grant No. JXQC-023), and High-level Introduction Talent Research Fund by Nanjing Institute of Technology, China (Grant No. YKJ201841). 


\section{References}

1. Yang, C.; Duan, L. L. 2015. Extract from Global Road Safety (2013), Injury Medicine (Electronic Edition) 4: 60-61 (in Chinese). https://doi.org/10.3868/j.issn.2095-1566.2015.01.013.

2. Rajandram, R. K.; Omar, S. N. S.; Rashdi, M. F. N.; Jabar, M. N. A. 2014. Maxillofacial injuries and traumatic brain injury: a pilot study, Dental Traumatology 30: 128-132.

https://doi.org/10.1111/edt.12052.

3. Guleyupoglu, B.; Schap, J.; Kusano, K. D.; Gayzika, F. S. 2017. The effect of precrash velocity reduction on occupant response using a human body finite element model, Traffic Injury Prevention 18: 508-514. https://doi.org/10.1080/15389588.2016.1269896.

4. Majak, J.; Pohlak, M.; Eerme, M.; Velsker, T. 2012. Design of car frontal protection system using neural networks and genetic algorithm, Mechanika 4: 453-460. https://doi.org/10.5755/j01.mech.18.4.2325.

5. Tuchtan, L.; Piercecchi, M. D.; Bartoli, C.; Boisclair, D.; Adalian, P.; Léonetti, G.; Behr, M.; Thollon, L. 2015. Forces transmission to the skull in case of mandibular impact, Forensic Science International 252: 2228. https://doi.org/10.1016/j.forsciint.2015.04.017.

6. Huempfner-Hierl, H.; Schaller, A.; Hierl, T. 2015. Maxillofacial fractures and craniocerebral injuries-stress propagation from face to neurocranium in a finite element analysis, Scandinavian Journal of Trauma Resuscitation and Emergency Medicine 23:35. https://doi.org/10.1186/s13049-015-0117-z.

7. Nahum, A. M.; Smith, R.; Ward, C. C. 1977. Intracranial pressure dynamics during head impact, Proceeding of 21st Stapp Car Crash Conference, San Diego, USA, 339-366. https://doi.org/10.4271/770922.

8. Trosseille, X.; Tarriere, C.; Lavaste, F.; Guillon, F.; Domont, A. 1992. Development of a FEM of the human head according to a specific test protocol, Proceeding of 36th Stapp Car Crash Conference, San Diego, Warrendale, 235-253. https://doi.org/10.4271/922527.

9. Yang, B.; Fan, L. H.; Hu, M.; Tang Y.; Xiao, F.; Wang, J.; Cao, L. B. 2016. A Study on the Finite Element Model for Head Injury in Vehicle Collision Accident, Automotive Engineering 38: 168-173 (in Chinese). https://doi.org/10.3969/j.issn.1000-680X.2016.02.006.

10. Cock, D. D.; Stufken, J. 2000. On finding mixed orthogonal arrays of strength 2 with many 2-levelfactors, Statistics \& Probability Letter 50: 383-388. https://doi.org/10.1016/s0167-7152(00)00125-5.

11. Cormier, J.; Manoogian, S.; Bisplinghoff, J.; Rowson, S.; Santago, A.; McNally, C.; Duma, S.; Bolte, J. 2011. The tolerance of the frontal bone to blunt impact, Journal of Biomechanical Engineering 133: 1-7. https://doi.org/10.1115/1.4003312.

12. Willinger, R.; Baumgartner, D. 2003. Human head tolerance limits to specific injury mechanisms, International Journal of Crashworthiness 8: 605-617. https://doi.org/10.1533/cras.8.6.605.19261.

13. Weller, M. D.; Drake-Lee, A. B. 2006. A review of nasal trauma, Trauma 8: 21-28. https://doi.org/10.1191/1460408606ta355oa.

14. Aykan, A.; Guzey, S.; Avsar, S. 2015. Neodymium magnet injury causing nasal fracture: a case report, Turkish Journal of Trauma and Emergency Surgery 21: 231-234. https://doi.org/10.5505/tjtes.2015.46588.

J. Tian, Q. Wang, B. Yang

CONSTRUCTION OF THE HEAD FINITE ELEMENT

MODEL AND CRANIOCEREBRAL INJURY IN

FACIAL COLLISION ACCIDENT

S u m m a r y

This paper aims at predicting and evaluating the biomechanical response of the facial impact on head injury in a crash accident. With the combination of CT/MRI medical imaging technique, the 50th percentile head biomechanical model with detailed cranio-facial structure is established. After which the validity of the model based on the classical experimental data is verified. Based on the analysis of nine typical facial collision scenes, this work studies the propagation path of stress wave in the skull, then ICP, von Mises stress and shear stress distribution are achieved. It is proved that facial structure can absorb a large amount of impact energy to protect the brain. The propagation path and distribution of stress wave in the skull and brain determine the mechanism of brain injury, which provides a theoretic basis for the diagnosis, treatment and protection of craniocerebral injury caused by facial impact.

Keywords: facial collision, craniocerebral injury, finite element simulation, injury biomechanics.

Received January 08, 2019

Accepted June 14, 2019 